\title{
The Caribbean Diaspora and the Formation of Identity in Second Generation Immigirants
}

Leonicka Valcius is an undergraduate student at the University of Toronto, studying Caribbean Studies and European Studies. Her areas

of focus include migration and the social ramifications of economic development. Leonicka was born in Montreal and raised in South Florida. Her family immigrated to Canada from Haiti in the 1970's, and they have since spread all over North America and the Caribbean. Leonicka has familial ties to Montreal, Toronto, New Jersey, New York, Boston, Florida, the Bahamas, Cuba, the Dominican Republic, and, of course, Haiti chérie.

\section{$\underline{\text { Introduction }}$}

In the summer of 2008, I was fixated by the idea of homelessness. I did not mean the lack of shelter or a place to sleep; those could be provided by a house. I was more concerned with home as a community. Home in my conception was a place where I would belong and recognize myself in others. And that summer, I felt homeless.

I knew nothing of this "Canada" to which my parents were dragging me. Yes, my birth certificate and passport confirmed that I was indeed Canadian but I had no idea what that meant in a social or cultural context. How different were those Canucks, really? So complete was my ignorance of everything north of the $49^{\text {th }}$ parallel that I felt the need to do research. I made CBC.ca my homepage and would browse the articles in an attempt to glean information. Even so, 'those Canadians' felt completely foreign to me.

I would joke to my friends (and still do at times) that I was being exiled to an arctic tundra. Yet, if I were honest with myself, I 
would recognize that the United States was not 'home' either. My political voice was stifled because I was not a citizen. I was denied financial aid by top universities because I was "technically" an international student. The very reason for leaving was that the visas that granted us permission to stay in the country had expired. Despite the eleven years I lived in Florida, it was made clear that I did not belong.

This left me with Haiti. My ties with the country run deeper than legal documents can express. As the birthplace of my parents, Haiti still holds the nebulous position of native land. I say "nebulous" because the entire construct rested on a romanticized vision of a country and a people I had never visited. I know of Haiti only through the food my mother cooks, the music my father plays, the blagues my aunts and uncles tell, and the memories my grandmother keeps. But is that enough? Can I really construct an identity around hearsay? How can I attribute my sense of self to anything other than my lived experiences?

It is with these deeply personal questions in mind that I approached this paper. With the help of research I attempted to discover my place in the context of the Caribbean diaspora.

\section{$\underline{\text { Uprooted }}$}

"Diaspora" was not an unfamiliar word to me growing up. My parents used it all the time to describe what we were. They could have used "moun pays étrangê" as those still in Haiti called us, but diaspora was a nicer way to say it. Both meant that we had left our home to live in a foreign land. Despite my Canadian birth, I too was part of this "we." "We're not like them," my mother would say. "They don't like us."

The pattern of leaving the islands for Europe and North America was not uncommon. People with whom my father grew up scattered to the big cities of London, Paris, Boston, New York, Miami, and Montreal. Leaving Haiti was an achievement. At a gala hosted by Dr. Eric Pierre, the Honorary Consul General of Haiti, I met a man who described his reasons for leaving Haiti. He'd made the decision at about fifteen years old and knew that once he left he'd never go back. "I had dreams and goals," he explained in French, "and I didn't feel I could 
Leonicka Valcius - THE CARIBBEAN DIASPORA \& THE FORMATION OF IDENTITY IN

SECOND GENERATION IMMIGRANTS

achieve them in Haiti." Though he quickly reminded me that he can only speak for himself and that he was probably an exception, his motives are substantiated by the research. It is often the economic constraints of the Caribbean that drive people to emigrate. Migration becomes "their sole source of economic and social mobility," (Henry 1994, 31) with Europe and North America providing opportunities in work and education that were not available in the Caribbean.

The difficulty for a second generation immigrant comes when trying to discover the culture his or her parents left behind without the context. Even a seemingly mono-ethnic country like Haiti (Gowricharn 2006, 11) has vast amounts of diversity. This holds for the Caribbean as a whole. Reis contends that "the region is actually composed of a plethora of diasporas," making Caribbean immigrants living in the West "twice diasporised" - first from Africa (and other regions) to the islands of the Caribbean and then from the Caribbean to Europe and North America (Reis 2006, 46-47). Following that line of thinking, I would argue that second generation immigrants are twice displaced - twice uprooted.

What we now call the Caribbean is inhabited by the descendents of enslaved peoples from various regions of Africa, indentured servants from across South Asia, and in the case of Haiti, the last remaining Taino people which European colonizers have not managed to exterminate. From this historical plurality was the present Caribbean culture formed; melded from different global experiences to form a new and unique whole. Similarly, it can be deduced that a second generation immigrant will form a new culture - a new identity - from the various cultures that he or she encounters and experiences. James discusses this duality in his study of Trinidadian immigrant dubbed Mark:

...[for] Mark, as a diasporic Canadian, and especially as a generationand-a-half [immigrated to Canada between ages of eight and twelve] Caribbean Canadian, home necessarily involves a combination of his 'two worlds': Trinidad and Canada... The 'twoness,' or duality is represented in his perception of Trinidad as his birthplace, or 'roots,' a place that provided the foundational values upon which he has built his life and aspirations, and a place of belonging and cultural reference; and Canada as his place of residence, a place he 'likes,' that 
'has been great' to him, and that has provided and continues to provide the opportunities on which he can base his future. (James 2005, 247)

In my case however, how much of that new identity will be drawn from the Eurocentric culture in which I am immersed? What parts of my lived experiences confirm me to be "definitely Haitian"?

\section{Haitian by Association}

The company one keeps can provide insight into that person's perception of self. It is logical then to look at the strength and structure of Caribbean communities and kinship groups as a marker of ties to the "native land."

In my experience, church has been the primary place of gathering for Haitians abroad. In our first year in the Greater Toronto Area, my family did not meet even one other Haitian. That is until we went to church. My brother's first reaction to the congregation of thirty or so people who 'looked like us' was, "Where have my Haitians been hiding this whole time?" A Haitian church is often more like a community center than a place of worship. Immigrants who face their own struggles during the week are given a support group with whom they can share their frustrations and nostalgic stories of home. Henry also points out the church's instrumental role in social support and adaptation. Newly arrived immigrants can turn to the church for help, finding living accommodations and employment. The church also acts as a refuge for immigrants who arrive without documentation (Henry 1994, 240-41). In my experience, some immigrants establish contacts with the church before leaving Haiti so as to have a support system as soon as they arrive.

For the other six days of the week, second generation immigrants must still find a way to remain connected to their heritage and community. Many do this by way of culture based associations. As Olwig put it "...their most intensive exposure to Caribbean culture [occurred] when they attended their university, because it had a large number of students from the Caribbean who organized a Caribbean club" (Olwig 2004, 59). I can relate. In my first year at university (in Florida) I had attended several events hosted by the Haitian club on campus. Now in my third year at the University of Toronto, I have 
Leonicka Valcius - THE CARIBBEAN DIASPORA \& THE FORMATION OF IDENTITY IN SECOND GENERATION IMMIGRANTS

become active in the Caribbean Studies Students' Union and found a sense of solidarity and belonging there. I find it interesting that without these associations, I do relatively little to foster my Haitian heritage. This relates not only to the aforementioned duality, but also to a type of compartmentalization of the self in which I separate "Leonicka, the Canadian" from "Leonicka, the Haitian" and pick my persona depending on the context. Henry describes a similar situation in the narration of "Lara's" relationship with a Portuguese boyfriend:

Things that I liked doing that were from my cultural self I simply excluded him from it. We would go to cafés and [places] that were more westernized, but when I just wanted to get back into my own cultural origin roots - I just basically never included him in it. (Henry 1994, 94)

I would argue that the reverse is also true. There are sectors of my life that my Haitian family (my parents primarily but also some cousins) would perceive as 'acting white', or, more broadly, as 'acting like them' (them being any non-Haitian). Rather than try to explain this part of myself to them, I simply exclude them. It is no wonder then, that second generation immigrants "experienced more difficulty defining a singular source of identity" (Olwig 2004, 62). How can you be sure of your identity if you rarely have the opportunity to be completely you?

\section{CompasCreole and Other Cultural Staples}

The artistic expressions of culture are the most visible and obvious ways of transmitting and preserving heritage. Music, dress, and the oral tradition all constitute the most tangible response to the question of Caribbean culture. This is exemplified in Toronto's annual Caribana. Millions flock to Toronto to participate in a weekend of activities highlighting the Caribbean, culminating in a parade graciously sponsored by Scotia Bank. Though Reis asserts that this “...has helped the diaspora maintain that level of connectivity with the homeland through the diffusion of cultural images" (Reis 2006, 49) I would say that the very fact that celebrations of Caribbean culture have become mainstreamed and commercialized undermines that project of passing on cultural values to second generation immigrants. The music, 
costumes, and overall ambience of the event are a crude and hollow simulation of Caribbean carnivals and tradition, constructed as a means of reaping the economic benefits of increased tourism and to bolster the idea of Canada as a multicultural and accepting society.

To be authentic, culture must be perpetuated in the home. Weekends were always festive. I remember my brothers and I laughing at the misadventure of Bouki and Malice. My extended aunts and uncles would gather at my grandmother's house, eat frittai (various fried snacks including pork, plantains, and breadfruit), blast music in the backyard, and laugh and clap as my cousins and I learned to brassérien - what Anglophone Caribbeans would call 'wining.' These experiences are similar to those of other Caribbean peoples:

These parties were intimate in the sense that people were linked to each other through ties of friendship, family, and work...Carol recalls that...one of her aunts held "wining lessons for the rapidly Canadianized and stiffening pelvises of young Caibbean immigrants and Canadian-born generation... (Henry 1994, 171)

It seems that older family members do recognize the need to reinfuse traditions and cultural practices into the habits of the younger generation. However when families are forced to separate as mine was, the extended family structure is weakened or dissolved, leaving the young immigrant with few cultural cues.

\section{$\underline{\text { Neither or Both? }}$}

My academically induced search for self raised many more questions than it answered. Identity, it seems, has very little to do with locale. I am very much a product of my experiences and surroundings. This includes the Canadian and American norms and ideas to which I have grown accustomed, and the Haitian tradition and culture to which I can trace my heritage. Do I have to choose one over the other? Am I both Canadian and Haitian? It is not a stretch to see myself washing down a paté with a cup of Tim Horton's.

I feel it is more appropriate perhaps to say I am neither. My identity is quite distinct from a Haitian living in Haiti or even a Haitian who has immigrated to another part of the world (France for example). 
Gmelch rightly noted, in reference to immigrants who returned to their native Barbados to live, that "migrants often do not realize how much their attitudes have been altered by their experiences in the metropolitan society until they come home" (Gmelch 2004, 216). I am also distinct from the mainstream Canadian in that I am "doubly removed from becoming a Canadian. Thus [I am] not only born to parents who come from elsewhere, but...also non-white...This means that [I] can only become part Canadian, whether or not [I] want to have a hyphenated identity" (Olwig 2004, 60). Like the African, South Asian, and Taino people before me, I am in a position where, through no fault of my own, I was removed from what would have been my home. And like them I must meld different parts of my experiences to form a new whole. So far, I think I have managed to create a cohesive home that is not determined by where I am, but on who I choose to be. 


\section{Bibliography}

Gmelch, George. "West Indian Migrants and Their Rediscovery of Barbados." In Coming Home? Refugees, Migrants, and Those Who Stayed Behind, edited by Lynellyn D. Long and Ellen Oxfeld, 206-223. Philadelphia: University of Pennsylvania Press, 2004.

Henry, Frances. The Caribbean Diaspora in Toronto: Learning to Live with Racism. Toronto: University of Toronto Press, 1994.

James, Carl E. "'I Feel Like a Trini': Narrative of a Generation-and-aHalf Canadian." Chap. 9 in Diaspora, Memory, and Identity: A Search for Home, edited by Vijay Agnew, 230-253. Toronto: University of Toronto Press, 2005.

Olwig, Karen Fog. "Place, movement, and identity: processes of inclusion and exclusion in a 'Caribbean' family." Chap. 3 in Diaspora, Identity, and Religion; New directions in theory and research, edited by WaltraudKokot, KhachigTölölyan and Carolin Alfonso, 53-71. London: Routledge, 2004.

Reis, Michele. "The Modern to Late-Modern Period in the Caribbean Diaspora." Chap. 3 in Caribbean Transnationalism: Migration, Pluralization, and Social Cohesion, edited by Ruben Gowricharn, 4358. New York: Lexington Books, 2006. 